\title{
TERAPIA DE CASAL E VIOLÊNCIA: REFLEXÕES TEÓRICO-TÉCNICAS
}

Alan Bronz

Este trabalho teve como objetivo avaliar o papel da terapia de casal no tratamento e na prevenção da violência quando esta ocorre de forma recorrente no casal. Para tanto foram entrevistados quatro psicólogos, terapeutas de família e casal, que realizaram a especialização nesta área em instituições de formação da cidade do Rio de Janeiro. A análise das entrevistas demonstrou que a terapia de casal, pelo menos sob a perspectiva dos profissionais entrevistados, demonstra ser um importante recurso para lidar com a problemática em questão.

\section{BANCA:}

Terezinha Féres-Carneiro (Orientadora)

Andrea Seixas Magalhães

Miriam Felzenszwalb

Data de defesa: 26/03/2010 